\title{
The Devonian-Carboniferous boundary in the stratotype area (SE Montagne Noire, France)
}

\author{
Raimund Feist $^{1 *} \cdot$ Jean-Jacques Cornée $^{2} \cdot$ Carlo Corradini $^{3} \bullet$ Sven Hartenfels $^{4} \bullet$ Markus $^{*}$
} $\operatorname{Aretz}^{5} \cdot$ Catherine Girard ${ }^{1}$

${ }^{1}$ ISEM, UMR 5554, CNRS, IRD, Université Montpellier, Montpellier, France

2 Géosciences Montpellier, CNRS-Université de Montpellier-Université des Antilles, Pointe à Pitre, (FWI), France

${ }^{3}$ Dipartimento di Scienze Chimiche e Geologiche, Università di Cagliari, Cagliari, Italy

${ }^{4}$ Institut of Geology and Mineralogy, University of Cologne, Cologne, Germany

5 Géosciences Environnement Toulouse, UPS, CNRS, IRD, avenue Edouard Belin, Toulouse (France)

\section{* Corresponding author : $\underline{\text { Raimund.Feist@umontpellier.fr }}$}

\section{Abstract}

Sections with continuous sedimentation across the Devonian-Carboniferous (D-C) boundary in the Montagne Noire allow to build a virtual transect from shoreline to deep basin. Nearshore facies characterise the D-C boundary stratotype and neighbouring sections at La Serre in the Cabrières klippen domain and offshore facies are present at the Col de Tribes and Puech de la Suque sections in the Mont Peyroux nappe domain. Both domains exhibit equivalents of the Hangenberg Black Shale (HBS). At La Serre, an initial regressive trend is indicated by the presence of oculated trilobites in the topmost pre-HBS Wocklumeria Limestones. Above the HBS level, regressive depositional conditions characterise oolitic deposits that comprise lithic erosional flows with an admixture of transported shallow-water biotas. Maximum regression is recognised with the deposition of coarse breccias and local features of emergence prior to the first appearance of Protognathodus kockeli. The oolites are superseded by the transgression of outer shelf deposits. In the nappe domain, the HBS is intercalated in outer ramp nodular limestones, and it exhibits detrital elements pointing to its regressive nature. The regressive trend culminates than reverses when post-HBS carbonate sedimentation resumes. Protognathodus kockeli appears in the post HBS carbonates. Associated oculated trilobites indicate shallower bathymetric conditions than those of the pre- 
HBS Wocklumeria Limestones. Thereafter, replacement of sighted trilobites by blind ones and

the protognathodid biofacies by facies dominated by siphonodellids indicate a deepening trend. The near- and off-shore sites of the D-C transition permit correlation of short-term bathymetric fluctuations with faunal turnovers and entries of biostratigraphic markers.

Keywords Devonian-Carboniferous boundary - Montagne Noire - biostratigraphy $•$ sedimentary dynamics $\bullet$ bathymetric trends $\bullet$ near-shore - off-shore correlation

\section{Introduction}

Palaeozoic rocks of the Montagne Noire, at the external margin of the southern French Massif Central, underwent a complex poly-phased Variscan deformation that resulted in a piling of large-scale, south-facing recumbent folds emplaced during the latest Viséan (e.g. Arthaud 1970; Echtler 1990). Synorogenic flysch sedimentation comprises gravitational mass-flows with large, up to kilometric-sized olistolitic blocks of various pre-tectonic ages (Cabrières klippen, "Ecailles de Cabrières") (Engel et al. 1978). The rocks were affected by syntectonic metamorphism with decreasing intensity in the highest parts of the nappe pile, Hence, the south-eastern inverted portions of the Mont Peyroux nappe, including the Cabrières klippen (Fig. 1), are composed of highly fossiliferous sedimentary rocks with only locally very low-grade metamorphic overprint (conodont Colour Alteration Index between 2 and 4, Wiederer et al. 2002). This allows facies analyses and investigations on fine-scaled bioand chemostratigraphy to be conducted in good conditions of preservation.

During Devonian through early Carboniferous times the nappe successions exhibit an almost continuous carbonate succession that was deposited on a low-angle, flat ramp. After deposition in coastal environments related to the initial Devonian transgression on an eroded early Palaeozoic hinterland (Feist 1985), the depositional conditions subsequently changed with an increase in both depth and distance from the shore. In the Mont Peyroux nappe, the Devonian-Carboniferous transition is located in a succession of outer ramp nodular limestones ("supragriottes", Boyer et al. 1968), which contain a Hangenberg Shale horizon of a few decimetres in thickness. Conversely, contemporaneous environmental conditions were different in the source area from where the erratic Cabrières klippen originated including the La Serre olistolite where the D-C boundary stratotype was defined (Paproth et al. 1991). In this area the uppermost Devonian exhibits increasingly strong influence from a near-by 
shallow shoal or even emerged land that resulted in dominantly mixed carbonate and siliciclastic near-shore sedimentation at the Devonian-Carboniferous transition. Consequently, two domains, near-shore Cabrières klippen and off-shore nappe successions, are represented in the south-eastern Montagne Noire (Fig. 1). Description and comparison of these two domains using biostratigraphical and sedimentological markers to evaluate the currently debated D-C boundary definition is the purpose of this contribution.

\section{Cabrières klippen}

Sections spanning the Devonian-Carboniferous boundary in different blocks among the Cabrières klippen were first compared by Engel et al. (1980-81, fig. 6). While in most cases late Tournaisian strata conformably overstepped various levels of the Famennian lower and middle Griotte formations, a complete Devonian through early Carboniferous succession is exclusively exposed at La Serre. At this site, local facies of the late Famennian through early Tournaisian Griotte Group (Feist 1985; Korn and Feist 2007), including transitional beds across the D-C boundary, were subsequently investigated in trenched sections (Feist and Flajs 1987a, b; Flajs and Feist 1988; Kaiser 2009; Cifer et al. 2017; updates herein).

\section{La Serre E' D-C boundary stratotype section}

The GSSP for the base of the Carboniferous is defined in trench LS-E' (Fig. 2a) on the southern slope of La Serre Hill at about $125 \mathrm{~m} \mathrm{~S}$ of the top 252 and $500 \mathrm{~m}$ to the E of La Rouquette farmhouse, ca. $2.5 \mathrm{~km} \mathrm{~S}$ of Cabrières (Paproth et al. 1991; Feist et al. 2000). Many studies were conducted at the La Serre D-C stratotype section concerning conodonts (Engel et al. 1980-81, Feist and Flajs 1987a; Flajs and Feist 1988; Girard 1994; Kaiser 2009), ammonoids (Becker and Weyer 2004; Korn and Feist 2007), ostracods (Casier et al. 2002), trilobites (Flajs and Feist 1988; Brauckmann et al. 1993; Feist and Petersen 1995), brachiopods (Legrand-Blain \& Martinez-Chacon 1988), corals (Semenoff-Tian-Chansky 1988), fish (Derycke et al. 1995), and foraminifera and algae (Vachard 1988). In addition, detailed data on microfacies (Flajs and Feist 1988; Casier et al. 2002), isotope and element geochemistry (Brand and Legrand-Blain 1993, 2004; Buggisch \& Joachimski 2006; Bábek et al. 2016) are available.

The section displays the upper part of the local facies of the Montagne Noire Griotte Group straddling the D-C boundary (Figs. 2a, 3). The exposed base of the section, below Bed 64, comprises well bedded, compact, grey-beige platy calcilutites with intercalated 
calcisiltites. The former are organized into dm-thick beds with horizontal to oblique plane bedding, convolutes and ripple-marks at their top. As such they are interpreted as finegrained, distal turbidites. The facies becomes predominantly nodular towards the top (Beds 64-67), and terminates with a layer of dissociated micritic limestone nodules in a clayey matrix (Bed 68). These contain a few poorly preserved iron-oxide coated Wocklumeria sp., giant (up to $5 \mathrm{~mm}$ long) leperditiid-like ostracods and numerous, often fragmented small trilobites. The varied association of the latter is dominated by sighted taxa, phacopids (Omegops) and proetids (Pseudowaribole) (Fig. 4), whereas blind forms characterizing the deeper off-shore domain such as Helioproetus are rare, and in particular, Dianops and Chaunoproetus are missing. This may indicate a near-shore (inner ramp to lagoonal?), photic environment that recalls the shallow shelf paleoenvironment of the Velbert area (NW Rhenish Slate Mts) (Michels 1986). Topmost nodules of Bed 68 contain rich conodont faunas with the last Bispathodus costatus, Bi. ultimus ultimus, representatives of the Palmatolepis gracilis group and Pseudopolygnathus marburgensis trigonicus of the Bi. ultimus Zone. Though early protognathids are missing, the presence of Siphonodella praesulcata recorded by Kaiser (2009) may indicate the higher part of this zone.

The topmost Wocklumeria yielding nodular limestones are superseded by thin $\mathrm{cm}$ thick, greyish shale that tends to be squeezed out locally by gravity slide parallel to bedding, but it is well represented in neighbouring sections (trench $\mathrm{C}$ and F, Fig. 5). This compressed level (between Beds 68 and 69) is thought to be equivalent to the Hangenberg Black Shale (HBS). It is overlain by well-bedded, graded biodetrital oolitic limestones with reworked and/or transported bio- and litho-clasts. This $3.5 \mathrm{~m}$ thick package can be divided into the lower (Beds 70-81) and upper (84-97) calcoolitic units. These are separated by the intercalation of $80 \mathrm{~cm}$-thick clayey, sandy and conglomeratic levels (Beds 82-83) with oolites and reworked upper Famennian blocks and pebbles: the intermediate siliciclastic-calcareous unit (Flajs and Feist 1988). The lower calcoolitic unit displays normal or inversely graded bedding and its upper part contains oolitic lime breccias. The lower part of the upper calcoolitic unit displays lime lithic oolitic grainstones with hummocky cross stratification, changing upwards into fine-grained bioclastic wackestone to mudstone. The clayey interval between the oolitic units comprises matrix supported grains, and dm-sized reworked Famennian boulders that display microkarst features on the surface.

The lithic-oolitic coarse-grained limestones are interpreted as being deposited in a shallow, high energy depositional setting in the inner ramp (upper shoreface) (Wright and 
Burchette 1992; Merzeraud 2017). The clayey-conglomeratic beds of the intercalated

siliciclastic-calcareous unit are interpreted as mass-flow deposits in the inner ramp, with an erosional surface at the bottom and boulders issued from an emergent area. To sum up, from faunal content and facies analysis, these sediments were deposited in an oscillating upper littoral shoreface, foreshore, and lagoon depositional environments, with interbedded debris flows. Consequently, these rocks indicate a major regression representing the time equivalent of the regressive phase of the Hangenberg Event, probably equivalent to the Hangenberg Sandstone (HSS) at Drewer, Rhenish Slate Mts. (Kaiser 2009; Becker et al. 2016).

The upper oolitic unit is overlain by grey pyrite-rich calcilutites with few oolites, rich in brachiopods and trilobites, and microsparitic crinoidal limestones (Beds 98-100). Above Bed 100 the facies change abruptly into nodular fine-grained marly limestones that make up the topmost portion of the Montagne Noire Griotte Group. This $1.5 \mathrm{~m}$-thick succession is best exposed $20 \mathrm{~m}$ to the $\mathrm{W}$ of LS-E' in an auxiliary trench ("LS-E"). These limestones yielded few goniatites and deep-water anthozoans (Becker and Weyer 2004), smooth ostracods, and blind trilobites including Liobolina that indicate a deeper offshore, lower ramp environment.

The GSSP of the D-C boundary is located within the upper calcoolitic unit, between beds 88 and 89 (Fig. 2a) after the decision and ratification of ICS/IUGS in 1990, following the proposal of the relevant International D-C boundary Working Group (Paproth et al. 1991). The decision was based on the first occurrence of Siphonodella sulcata, but since the beginning this decision encountered criticisms due to difficulties to interpret intermediate morphotypes between Si. praesulcata and Si. sulcata (Ji et al. 1989, p. 72; Ziegler \& Sandberg 1996). Since the presence of Si. sulcata is recognized in Bed 84b (Kaiser 2009) the position of the GSSP is currently called into question. With regard to the problem of controversial assignments of early siphonodellids, the potential using protognathodids as a tool to define the D-C boundary has currently gained interest (Corradini et al. 2016). In this context, the successive appearance of index forms of this group in section LS-E' is of utmost importance.

Early protognathodids, i.e. Protognathodus collinsoni and Pr. meischneri, are present throughout the succession after their entry in Bed 70. Protognathodus kockeli occurs at the base of the upper oolitic unit (Bed 84a) defining the onset of the Pr. kockeli Zone above the levels of maximum regression (top Bed 81). This correlates with sections in the Rhenish Slate Mountains where $P r$. kockeli invariably enters above the regression of the Hangenberg Sandstone (Becker et al. 2016). Protognathodus kuehni enters in the middle of the upper 
oolitic unit (Bed 93) shortly above the GSSP. Early and late protognathodids occur abundantly among many reworked Late Devonian conodonts in Beds 98-100. The Si. bransoni Zone starts in Bed 98 with the entry of Si. bransoni (Fig. 6). Thus, the Pr. kockeli/Si. bransoni zonal boundary coincides with the top of the calcoolitic units.

Among macrofaunal biostratigraphical markers at the D-C boundary ammonoids are virtually absent with the exception of a single specimen of Acutimitoceras intermedium in Bed 90 characterizing the basal Carboniferous. Trilobites are absent in the lower calcoolitic units and appear sporadically in the siliciclastic debris-flow unit (Beds 82-83) with poorly preserved fragments of Pudoproetus sp. and ?Mirabole sp. The former usually does not appear prior to the entry of Protognathodus kockeli and this might questionably indicate an extension of the Pr. kockeli Zone below Bed 84a. Trilobites are relatively abundant in the upper calcoolitic unit (Feist in Flajs and Feist 1988). New collections indicate that Pudoproetus mediterraneus and Brachymetopus germanicus are present as early as Bed 84 . Conversely, Belgibole abruptirhachis, a worldwide marker of the kockeli Zone (Yuan and Xiang 1998) has not been found below Bed 89 and Winterbergia (?Eowinterbergia) cf. funirepa occurs later in Beds 90-92. Instead of a late entry of these two index taxa at La Serre, their absence in Bed 84 might result from sampling bias rather than from facies control.

\section{La Serre $C$ and F sections}

La Serre trench C (LS-C) and trench F (LS-F) sections are situated respectively $100 \mathrm{~m}$ east and $150 \mathrm{~m}$ west of the present Global Stratotype Section and Point (GSSP) (Fig. 5). Though different in thickness, these sections exhibit a rather similar succession.

The section LS-C (Fig. 5e) exposes a similar succession than that of the section LS-E', but indicates a slightly more distal deposition. In contrast to the stratotype section, the Hangenberg Black Shale (HBS) equivalent (Bed 54k) is well-developed (30 cm thick) below the regressive lower calcoolitic unit (Beds 541 to 55g) (Cifer 2016; Cifer et al. 2017). Conodonts and trilobites recorded below the HBS are the same as in LS-E' 68 indicating the presence of the higher part of the Bispathodus ultimus Zone. Whereas only reworked conodonts were found in the calcoolitic and siliciclastic units, the presence of the Si. bransoni Zone is established in the superseding yellow nodular limestones (Bed 58u), based on lithology. The uppermost strata of the Montagne Noire Griotte Group, i.e. the yellow nodular limestone above the oolites, are topped by a recurrent oolitic bed with reworked bioclasts with plant remains. This bed yielded a rich and divers siphonodellid association including Siphonodella quadruplicata and Si. crenulata (Engel et al. 1980-81, fig. 6). This bed is 
superseded by black marls and chert bearing shales with numerous compressed plant remains

(Galtier et al. 1987). These rocks are considered representing a particular facies of the Lydiennes Formation (basal St. Nazaire Group, Korn and Feist 2007).

The section LS-F (Fig 5a) has a $20 \mathrm{~cm}$-thick HBS horizon (Bed 18) with numerous phytoclasts of terrestrial origin (R. Brocke, det.). It is superseded by three carbonate units and two clayey beds with Famennian reworked boulders (Bed 22) or oolitic boulders (Bed 25). The lower carbonate unit (Beds 19-21) comprises fine-grained and bioclastic platy beds and dm-thick oolitic beds above. The top of Bed 21 with Protognathodus collinsoni (Fig. 6) displays karst erosional gullies, which indicate of a local subaerial surface (Fig. 5a). The intermediate siliciclastic units (Beds 22 and 25) are much thicker (ca $2.5 \mathrm{~m}$ ) then in trench LS-E', and the intercalated calcoolitic unit (Beds 23-24) is questionably emplaced by gravity slide. The uppermost oolitic unit (Beds 26 to 28) is rich with accumulations of large-sized, dissociated brachiopod shells and fewer remains of oculated trilobites including Belgibole abruptirhachis. Rare cases of reworked Omegops occur as intraclasts. Above Bed 28, the uppermost coarse-grained oolitic unit changes into micritic, grey cephalopod limestones superseded by siliceous shales (lydites). The succession from Beds 18 to 28 is interpreted as a slightly more proximal setting than LS-C and LS-E.

\section{Geochemistry}

Though caution is warrated in the investigation of almost entirely reworked and/or transported materials, studies on carbon and oxygen isotopes have been conducted on oolitic limestones at La Serre LS-E' by Buggisch and Joachimski (2006) and on brachiopod shells by Brand et al. (2004) for the succession across the D-C boundary. Temperatures found by Brand et al. (2004) are not well constrained, but suggest a cooling peaked near the D-C boundary. Strontium isotope studies on unaltered brachiopod shells at La Serre E' reflect changes in continental weathering patterns and are congruent with data obtained by Bábek et al. (2016). Elevated percentage of detrital proxies was interpreted as an increase of siliciclastic input, which possibly reflects records of a glacio-eustatic sea-level drop. Furthermore, the cooling indicated by the positive oxygen isotope peak preceding the carbon cycle perturbation, as indicated by a peak in carbon isotopes, record global carbon cycle perturbations prior to the D-C boundary (Bábek et al. 2016, Kaiser et al. 2008). 


\section{Mont Peyroux nappe domain}

The Devonian-Carboniferous transition in the nappes is characterized by distal ramp settings of uniform grey nodular cephalopod limestones (Montagne Noire Griottes Group, Korn and Feist 2007) in which a pluri-decimetres thick Hangenberg Shale is invariably interbedded. At Mont Peyroux, the Col de Tribes and Puech de la Suque sections have been studied in detail, whereas at Pic de Bissous only preliminary data are available to date (Korn and Feist 2007; Aretz et al. 2016).

\section{Col des Tribes section}

The Col des Tribes section (Figs. 2b, 7) is situated about $2 \mathrm{~km} \mathrm{~N}$ of Causses-et-Veyran and about $1.5 \mathrm{~km}$ to the $\mathrm{SSW}$ of the Puech de la Suque section. This section displays a complete inverted succession from upper Frasnian (approximately Lower Kellwasser horizon) to the Tournaisian (Lydiennes Formation) (Girard et al. 2014). This section is rather similar to the Puech de la Suque, but is depositionally in a slightly more proximal position with regard to its geographical position on the inverted limb of the Mont Peyroux nappe. At Col des Tribes, previous studies across the D-C boundary beds concerned ammonoids (Price and House 1984; Becker and Weyer 2004; Korn 2005), actinopterygian fishes (Gauchey et al. 2014), as well as conodonts and carbonate microfacies (Girard et al. 2014).

The Devonian-Carboniferous boundary interval starts with cephalopod-rich mudstone to wackestone beds (Beds CT70 to CT70-3 of Girard et al. 2014) with reduced eyed (Haasproetus) and blind (Chaunoproetus) trilobites (Fig. 8), ostracods, bivalves, brachiopods, crinoids, and filaments (pelagic bivalves) deposited in an outer platform setting. This $2.8 \mathrm{~m}$ thick package can be attributed to the late Famennian Bispathodus ultimus Zone (Girard et al. 2014). It is superseded by $0.5 \mathrm{~m}$ of dark shales (between Beds CT70.3 and DC1) comprising a thin inter-bed of dolomitized yellowish limestone. The shale interval is overlain by $3 \mathrm{~m}$ of thick wackestone- to packstone-beds with poorly preserved ammonoids (Levels DC1 to CT75). In the lower meter of these limestones, ammonoids are associated with crinoidal remains. Blind trilobites (Liobolina) occur at the top beds (upper part of level CT75) preceding the black bedded cherts ("Lydiennes Formation") of the St. Nazaire Group.

The Beds DC2 and DC3 just above the Hangenberg Shale equivalent contain Protognathodus kockeli. The Si. sulcata Zone is present in levels DC4 and DC5 (Fig. 6). The 
Si. bransoni Zone is recognized in level DC6 (equivalent of the level CT70-7 in Girard et al 2014). Above, the base of the Si. duplicata Zone has been discriminated in Bed DC13. Bed CT72 belongs to the Si. jii Zone due to the first occurrence of Siphonodella cooperi. The Si. sandbergi Zone is defined by the occurrence of Pseudopolygnathus triangulus triangulus, and then the Si.quadruplicata Zone is recognized just before the black chert deposits in level CT75.

\section{Puech de La Suque section}

The Puech de la Suque (PS) section (Figs. 2c, 9) is situated along a vineyard track on the eastern and south-eastern slope of Puech de la Suque hill about $2.2 \mathrm{~km} \mathrm{SE}$ of Saint Nazaire-de-Ladarez. The overturned section exposes a continuous succession of upper Famennian to mid-Tournaisian strata belonging to the Montagne Noire Griotte Group and St. Nazaire Group (Korn and Feist 2007). The Devonian-Carboniferous boundary transition is situated in the upper part of the Montagne Noire Griotte Group ("supragriottes" Boyer et al 1968). It was studied for conodonts (Boyer et al. 1968; Girard 1994; Kaiser et al. 2009), ostracods (Lethiers and Feist 1990, Casier et al. 2001), ammonoids (Korn and Feist 2007), sedimentology (Michel 1971, Casier et al. 2001) and geochemistry (Kaiser et al. 2008; Bábek et al. 2016, Fačevicová et al. 2016).

The investigated topmost Wocklumeria limestone succession of the Montagne Noire Griotte Group (Beds PS85 to PS90) consists of bedded, nodular dm-thick micritic limestones with dominant cephalopods and filaments (pelagic bivalves), blind trilobites (Chaunoproetus) and predominantly Thuringian-type ostracods (Casier et al. 2001) that indicate a quiet offshore environment below the photic zone. The topmost Bed 90 (of Girard 1994) is rich in Wocklumeria denckmanni and conodonts including Bispathodus costatus, Bi. ultimus, representatives of the Palmatolepis gracilis group and Si. praesulcata of the Bispathodus ultimus Zone. No early protognathodids occur. The top of Bed PS90 displays iron coatings. It is overlain by $5 \mathrm{~cm}$ of yellowish shale with few calcareous iron-coated nodules, followed up by $1 \mathrm{~cm}$ of thick stripped shale, then by $26 \mathrm{~cm}$ of dark shale (Fig. 10), which is thought to be equivalent to the Hangenberg Black Shale horizon (HBS) of the pelagic realm. We determined the mineralogy of the HBS and quantified their components by X-ray diffraction at the University of Montpellier using Philips X'Pert PRO MPD diffractometer and PANalytical X'Pert HighScore Plus version 3.0.5 software; each sample was analysed during $1 \mathrm{~h}$ between 5 and $60^{\circ}$ Theta, with a $0.033^{\circ}$ Theta step. The presence of organic matter and 
oxidised pyrite between Beds Hjb2 and HB1 probably indicates momentarily dysoxic conditions. Thin-sections and X-ray analysis of the silty greyish to black shales, devoid of carbonates, reveal the presence of detrital quartz and muscovite grains that make up to $80 \%$ of the whole rock as well as berlinite grains, a high temperature mineral (Fig. 10). The allochthonous origin of the sand indicates erosion of distant emergent areas, and emphasises the regressive nature of this level. Using the maximum and minimum amounts of quartz and muscovite (easily transportable), two minor regressive/transgressive cycles can be interpreted from Beds PS 89 to Hjt1. Neither conodonts nor spores were found in the shales and among scarce cephalopod remains poorly preserved and undeterminable pyritic protoconchs of ammonoids occur. Besides the bearing of innumerable dissociated bivalves, preliminary study reveals the presence of rare scolecodonts and acritarchs (R. Brocke, det.). The shales are topped by $10 \mathrm{~cm}$ of silty, yellowish decalcified mudstone (Fig. 2a: star) with numerous bivalves and filaments (pelagic bivalves), in which a specimen of Bispathodus stabilis ssp., a few specimens of the Polygnathus communis group, and indeterminable ramiform conodonts were found. The shales are superseded by the reappearance of carbonate sedimentation with 2 $\mathrm{m}$ of grey-yellowish, nodular, dm-thick bedded mudstone to wackestone. At the base, nodules of biomicritic limestones (Bed PS10a, Fig. 2c) in shaly matrix yielded the first Protognathodus kockeli and partly silicified ostracods, bivalves, filaments (pelagic bivalves) and abundant goniatites (Acutimitoceras subbilobatum, A. intermedium). In the bodychambers of the latter oculated juvenile trilobites (Belgibole abruptirhachis and Winterbergia (?Eowinterbergia) funirepa) are abundant (Fig. 8). The exclusively normally oculated nature of the trilobites points to level-bottom conditions within the photic zone and a minimum in paleobathymetry. Protognathodus kockeli enters in Bed PS10a (Bed numbers from Girard, 1994) (Fig. 6). Bed PS 11 yielded Gattendorfia subinvoluta in a fine-grained matrix with crinoid ossicles and trilobite remains. Above the base of the Protognathodus kockeli Zone, Siphonodella sulcata enters the succession in Bed PS 11 (Bed 12a of Kaiser 2009), Si. bransoni in Bed 13, Si. duplicata in Bed 15, Si. jii in Bed 17, Pseudopolygnathus triangulus triangulus indicating the base of the Si. sandbergi Zone in Bed 23, and Si.quadruplicata in Bed 25. This nodular limestone succession corresponds to the Hangenberg Limestone of the Rhenish Slate Mountains. It progressively changes upwards into shales with fewer and fewer limestone nodules of late early Tournaisian age. Abundant silicified trilobite remains and ostracodes occur in the highest limestone nodules (Bed 28) preceding the black bedded cherts of the St. Nazaire Group (Lerosey-Aubril 2005, Lethiers and Feist 1990). In these beds, predominance of ostracodes of Thuringian eco-type and blind trilobite individuals such as 
Liobolina (Fig. 8) indicate bottom conditions below the photic zone while siphonodellids dominate the conodont associations (Girard 1994).

Due to diagenetic overprinting, $\delta^{13} \mathrm{C}$ values at Puech de la Suque are not available (Buggisch and Joachimski 2006), but the analyses of major and trace elements by Bábek et al. (2016) provided the same trends as those observed at La Serre LS-E' section, assuming a rapid sea-level drop at the Hangenberg Event. For both areas, analyses of organic carbon (TOC) do not reveal characteristic lithological features for black shales and very little or no evidence for water dysoxia/anoxia (Kaiser et al. 2008; Bábek et al. 2016), as found at Puech de la Suque where only $1 \mathrm{~cm}$ of stripped shales occur.

\section{Bathymetric trends and nearshore - offshore correlations}

According to the model of Engel et al. (1980-81) the Cabrières sedimentary klippen were intercalated, after gravity transport, into higher parts of the flysch succession [Laurens Flysch Group of Korn and Feist (2007), Laurens-Cabrières Group of Vachard et al. (2017)] that composes the normal limb of the Mont Peyroux nappe. The recumbent fold nappes, such as the Mont Peyroux nappe, and the concomitant syntectonic sedimentary transport with gravitational flows of exotic blocks, such as the Cabrières klippen, were emplaced with the same north (internal) to south (external) polarity (Engel 1984). Thus, a southward directed movement of nappe emplacements (e.g. Arthaud 1970; Echtler 1990) implies that the source area of the exotic Cabrières klippen, including La Serre, has to be farther to the north than the site from where the nappes originated. This model is supported by sedimentary and biofacies criteria that indicate shallower depositional conditions of the Devonian-Lower Carboniferous succession in the klippen that were closer to the shoreline (Feist and Echtler 1994) than the nappes.

At La Serre sea-level fluctuations across the D-C boundary levels were previously interpreted by Flajs and Feist (1988) and Casier et al. (2002) based on section LS-E'. These interpretations are refined herein based on new data and observations from section LS-E' and the adjacent sections LS-C and LS-F. In the upper part of the Famennian, preceding the HBS horizon, the water depth decreases, with depositional environments changing from outer to mid ramp (LS-E', Beds 56-67; LS-C, Beds 52-54; LS-F, Beds1-17) to inner ramp setting of the lower carbonate/oolitic units. This regressive trend is also indicated by the presence of predominantly oculated trilobites and leperditiid-like ostracods that characterise nearshore 
environments in LS-E' Bed 68 (= equivalents of the upper Wocklumeria Limestones). The

onset of oolitic sedimentation marks a pronounced regression that culminates in the deposition of lime breccias (LS-E' $80-81$ and LS-C 55f-g) and in a local emergence (above Bed 21 in trench LS-F), below the debris flow deposits. Noticeably, the correlation between the three investigated sections (Fig. 11) at La Serre show that this emergence surface is erosional westwards as several beds of the lower calcoolitic unit of section E' are missing in section F. The existence of an emergence surface is also indicated by 1) Devonian boulders with karst phenomena in the debris flows at La Serre E' and C, indicative of neighbouring emerged areas, 2) evidence of erosional hardgrounds and hiatuses in sections of other Cabrières klippen (e.g. Tourière, Engel et al. 1980-81: fig. 6) and 3) by the overwhelming percentage of reworked late Frasnian (ancyrodellids) to Famennian conodonts in calcoolitic units, indicative of the removal of at least 50 meters of Late Devonian outer-shelf carbonate deposits (Feist 1985). Above the lower carbonate/calcoolitic unit a transgressive trend occurs with first the deposition of the debris flow in inner ramp setting, then the deposition of carbonate units. At the onset of the upper oolitic unit Protognathodus kockeli appears (Bed LS-E' 84). This transgressive trend, progressively developed in succeeding beds with lithicoolitic deposits of shoreface to mid-ramp environments changes upwards into nodular mudstones of the outer ramp (offshore).

Regarding bathymetry, the nappe-sections Col des Tribes and Puech de la Suque are clearly in a more distal position than the sections at La Serre. The latest pre-Hangenberg Griotte limestones of the Bispathodus ultimus Zone, in particular, are homogenously biomicritic, nodular and devoid of shallow-water biotas. The extremely rich content of clymenids (Wocklumeria) in the last beds preceding the HBS level indicates a pelagic outer platform environment where no regressive trend is discernable. In particular, the presence of blind and reduced eyed trilobites, such as Chaunoproetus, Haasproetus and Struveproetus (Fig. 8), emphasizes level-bottom habitats that remained below light penetration, and this contrasts with equivalent levels at La Serre. This contrast is interpreted as a result of water depth below the photic zone in the Mont Peyroux nappe sections where the record of the regression remained cryptic. However, based on detrital influxes, the regressive trend becomes obvious as outer platform (Wocklumeria Limestone) environments change to a midplatform setting during deposition of the Hangenberg Shale above Bed Hjb2. The maximum regression is supposed to correlate at the top of the yellow mudstone above the HBS, within a level between Hjt2 and PS10a (Fig. 10) prior to the entry of Protognathodus kockeli (Beds DC2 at Col des Tribes and PS10a at Puech de La Suque). This extremely condensed level 
between the yellow mudstone and the first limestone nodules with Protognathodus kockeli must correspond, arguably, to the emergence level at La Serre (top Bed 21 in LS-F). Above, a transgressive trend developed from mid platform to outer platform settings during the early Tournaisian part of the Montagne Noire Griotte Group, succeeded by a basinal, poorly oxygenated setting of the Lydiennes Formation.

The correlation of near-shore sections at La Serre and off-shore sections of the Mont Peyroux nappe are based on sedimentological, geochemical, palaeoecological and biostratigraphical criteria. In this regard the palinspastic position of the DevonianCarboniferous transition in both areas can be comparably placed on a proximal-distal transect: the La Serre olistolite in a near-shore situation under direct influence of coarse erosional input from the close-by source area and, on the other hand, the Puech de la Suque and Col de Tribe nappe sections were in a distal outer shelf position with fine-grained, long-distance detrital input (Fig. 11). The distance between both sites remains unknown; however Engel et al. (1980-81) demonstrated that both are intimately linked to the same tectono-sedimentary complex of the Mont Peyroux nappe and, as such, their source areas may not have been separated by considerable distances.

\section{Conclusions and perspectives}

The Montagne Noire offers the unique opportunity to compare and potentially correlate condensed distal basinal settings with contemporaneous near-shore carbonates that, following the HBS level, stood under direct influence of an emerged hinterland. As such the latter reflect sea-level variations corresponding to the degree of intensity and nature of detrital input from the near by source area. Regardless of the overwhelming percentage of reworked conodonts in these near-shore sediments, the first appearances of index forms such as Protognathodus kockeli, Pr. kuehni, and Siphonodella bransoni allow the succession to be dated. The top of the lower calcoolitic unit and the intermediate siliciclastic unit bear evidence of maximum regression which can be correlated with the top of the yellow organo-detrital mudstones that superseds the HBS in the outer-shelf sections of the nappe domain. In the latter, the maximum regression occurred at the end of the HBS shale deposits and slightly before the onset of the post-event carbonate sedimentation that yield the first Protognathodus kockeli. The reappearance of outer ramp griotte limestones may initially correspond to shallower bathymetric conditions than those of pre-Hangenberg times, as indicated by the presence of trilobites exclusively with large eyes. This initially relatively shallower period 
might correspond to the time-interval of the upper oolitic unit at La Serre. Thereafter, from

the beginning of the Siphonodella bransoni Zone onwards, transgressive trends lead to subphotic zone deep water conditions in both areas with blind trilobites and the increase of siphonodellids. The correlation of bathymetric trends between both sites is of utmost importance in the search to locate the turnover between the Hangenberg regression and the onset of the post-Hangenberg transgression, a crucial criterium in the debate to redefine the D-C boundary. Ongoing work focuses on search for sections in intermediate position between proximal and distal sites on the transect La Serre - Puech de la Suque. It is speculated that in such intermediate, mid-ramp sites fine-grained carbonate sedimentation resumes, superseding the HBS level beyond reach of coarse detrital input. Such post-HBS carbonates would be contemporaneous with the condensed yellow mudstones at the top of the HBS at Puech de la Suque. The SE Montagne Noire constitutes a great potential for recovering such sites.

The D-C boundary sections of the Montagne Noire emphasise the importance of the Hangenberg Event affecting marine biotas in both near- and off-shore domains. As in the Rhenish Slate Mountains and Carnic Alps for example, the biotic turnover is particularly marked in the outer shelf domain; it seems the same in the near-shore domain of La Serre, though the evidence is obscured by reworking processes during deposition of detrital input. As elsewhere, the Hangenberg Event in the Montagne Noire is characterised mainly by eustatic perturbations, notably regressive trends in the topmost Wocklumeria Limestones and during the HBS and HSS, followed up by a global transgression above. Among level-bottom biotas with light receptors, trilobites are most sensitive to changing conditions in the degree of light penetration to their habitats. With the onset of the HBS regression they lost all lowerrank taxa (genera and species) and none of them survived the crisis. The taxonomic origination rate following the HBS/HSS regression in both domains is outstanding, leading to evolutionary lineages after the explosion of Pudoproetus and Winterbergia that characterise the early Carboniferous radiation. As such, the position of the D-C boundary at the base of the post-event transgression is favoured, as it coincides with a marked faunal overturn that permits tracing a time-line from shore to off-shore domains.

\section{Acknowledgements}

We are greatly indebted to the owner of "la Rouquette" farm, Maryse Boisgontier for her kind permission to investigate on her ground at La Serre, to Dieter Korn (Berlin), Rainer Brocke 
(Frankfurt) and Bruno Milhau (Lille) for determining ammonoids, palynomorphs and ostracods, respectively. We thank Claudia Spalletta (Bologna) and Jeff Over (Geneseo, NY) for their insightful comments on the manuscript. Sandra Kaiser (Stuttgart) provided information on conodonts of her own collections from LS-E' and PS, and helpfully contributed to the discussion on biostratigraphical significance of index taxa. Anne-Lise Charruault and Suzanne Jiquel (Montpellier) helped efficiently in the field. We thank B. Fraisse who performed the RX diffraction analysis (Réseau de Rayons X et Gamma Z, Ressource technologique de l'Université de Montpellier) and Doriane Delmas and Christophe Nevado for performing thin slices of rock-samples. The research was supported by the ANR Project ECODEV (ANR-13-BSV7-005) and the Projet Marcon (Labex CeMEB). This is contribution ISEM 2019-072.

The authors declare that they have no conflict of interest.

This article does not contain any studies with human participants or animals performed by any of the authors.

\section{References}

Aretz, M. (2016). The Kulm Facies of the Montagne Noire (Mississippian, southern France). Geologica Belgica, 19, 69-80.

Aretz, M., Corradini, C., Cornée, J.-J., Feist, R., \& Girard, C. (2016). A new look on the Devonian - Carboniferous Boundary. Fieldguide to the DCB section in the SE Montagne Noire. International Workshop of the joined SDS-SCCS Task Group, Montpellier Sept. $2016,29 \mathrm{p}$.

Arthaud, F. (1970). Etude tectonique et microtectonique compare de deux domaines hercyniens: les nappes de la Montagne Noire (France) et l'anticlinorium de l'Iglesiente (Sardaigne). Thesis, University of Montpellier, $175 \mathrm{pp}$.

Bábek, O., Kumpan, T., Kalvoda, J., \& Grygar, T.M. (2016). Devonian/Carboniferous boundary glacioeustatic fluctuations in a platform-to-basin direction: A geochemical approach of sequence stratigraphy in pelagic settings. Sedimentary Geology, 337, 81-99.

Becker, R.T., Hartenfels, S., Weyer, D., \& Kumpan, T. (2016a). The Famennian to Lower Viséan at Drewer (northern Rhenish Massif). In R.T. Becker, S. Hartenfels, P. Königshof \& S. Helling (Eds.), Middle Devonian to Lower Carboniferous stratigraphy, facies, and 
bioevents in the Rhenish Massif, Germany - an IGCP 596 Guidebook. Münstersche Forschungen zur Geologie und Paläontologie, 108, 158-178.

Becker, R.T., Kaiser, S.I., \& Aretz, M. (2016b). Review of chrono-, litho- and biostratigraphy across the global Hangenberg Crisis and Devonian-Carboniferous Boundary. In R.T. Becker, P. Königshof \& C.E. Brett (Eds.), Devonian Climate, Sea Level and Evolutionary Events. Geological Society, London, Special Publications, 423, 355-386.

Becker, R.T., \& Weyer, D. (2004). Bartzschiceras n. gen. (Ammonoidea) from the lower Tournaisian of southern France. Mitteilungen des Geologisch-Paläontologischen Instituts, Universität Hamburg, 88, 11-36.

Bischoff, G. (1957). Die Conodonten-Stratigraphie des rhino-herzynischen Unter-Karbons. Abhandlungen des hessischen Landesamtes für Bodenforschung, 19, 64 p.

Boyer, F., Krylatov, F., Lefèvre, J., \& Stoppel, D. (1968). Le Dévonien supérieur et la limite Dévono-Carbonifère en Montagne Noire (France), lithostratigraphie - biostratigraphie (conodontes). Bulletin du Centre de Recherches Pau-SNPA, 2, 5-33.

Brand, U., \& Legrand-Blain, M. (1993). Paleoecology and biochemistry of brachiopods from the Devonian-Carboniferous boundary intervals of the Griotte Formation, La Serre, Montagne Noire, France. In M. Streel, G. Sevastopoulo \& E. Paproth, E. (Eds.), DevonianCarboniferous boundary. Annales de la Société géologique de Belgique, 115(2), 497-505.

Brand, U., Legrand-Blain, M., \& Streel, M (2004). Biochemostratigraphy of the DCB global stratotype section and point, Griotte Formation, La Serre, Montagne Noire, France. Palaeogeography, Palaeoclimatology, Palaeoecology, 205, 337-357.

Branson, E.B., \& Mehl, M.G. (1934). Conodont Studies. University of Missouri Studies, 4, 265-344.

Brauckmann, C., Chlupáč, I. \& Feist, R. (1993): Trilobites at the Devonian-Carboniferous boundary. In M. Streel, G. Sevastopoulo \& E. Paproth, E. (Eds.), Devonian-Carboniferous boundary. Annales de la Société géologique de Belgique, 115(2), 507-518.

Buggisch, W., \& Joachimski, M.M. (2006). Carbon isotope stratigraphy of the Devonian of Central and Southern Europe. Palaeogeography, Palaeoclimatology, Palaeoecology, 240, $68-88$.

Casier, J.-G., Lethiers, F., \& Préat, A. (2002). Ostracods and sedimentology of the DevonianCarboniferous stratotype section (La Serre, Montagne Noire, France). Bulletin de l'Institut royal des Sciences de la Terre, 73, 83-107. 
Cifer, T., Corradini, C., Girard, C., Hartenfels, S., \& Kaiser, S.I. (2017). A new Devonian/Carboniferous boundary section in the stratotype area (La Serre, Montagne Noire, France). In J.-C. Liao \& J.I. Valenzuela-Rios (Eds.), International Conodont Symposium (ICOS 4), Valencia (Spain). Publicationes del Instituto geologico y minero de España, Abstracts, 199.

Corradini, C., Spalletta, C., Mossoni, A., Matyja, H., \& Over, D.J. (2017), Conodonts across the Devonian/Carboniferous boundary: a review and implication for the redefinition of the boundary and a proposal for an updated conodont zonation. Geological Magazine, 154(4), 888-902. doi: 10.1017/S001675681600039X

Derycke, C., Blieck, A. \& Turner, S. (1995). Vertebrate microfauna from the Devonian/Carboniferous boundary stratotype at La Serre, Montagne Noire (Hérault, France). Bulletin du Museum National d'Histoire Naturelle, 17 (C), 461-485.

Echtler, H. (1990). Geometry and kinematics of recumbant folding and low-angle detachment in the Pardailhan nappe (Montagne Noire, Southern French Massif Central). In P. Matte (Ed.), Terranes in the Variscan Belt of Europe and Circum-Atlantic Palaeozoic Orogens. Tectonophysics, 177, 109-123.

Engel, W. (1984). Migration of folding and flysch sedimentation on the southern flank of the Variscan Belt (Montagne Noire, Mouthoumet Massif, Pyrenees). Zeitschrift der Deutschen Geologischen Gesellschaft, 135, 279-292

Engel, W., Feist, R., \& Franke, W. (1978). Synorogenic gravitational transport in the Carboniferous of the Montagne Noire (S-France). Zeitschrift der Deutschen Geologischen Gesellschaft, 129, 461-472.

Engel, W., Feist, R., \& Franke, W. (1980-81). Le Carbonifère ante-stéphanien de la Montagne Noire: rapports entre mise en place des nappes et sédimentation. Bulletin du B.R.G.M., $2^{\text {ème }}$ série I, 4, 341-389.

Fačevicová, K., Bábek, O., Hron, K., \& Kumpan, T. (2016). Element chemostratigraphy of the Devonian/Carboniferous boundary. A compositional approach. Applied Geochemistry $75,211-221$.

Feist, R. (1985). Devonian Stratigraphy of the Southeastern Montagne Noire (France). In W. Ziegler and R. Werner (Eds), Devonian series boundaries - results of worldwide studies. Courier Forschungsinstitut Senckenberg, 75, 331-352. 
Feist, R., \& Echtler, H. (1994). Biostratography and Dynamics of the nonmetamorphic sedimentary record. External zones. In J. D. Keppie (Ed.), Pre-Mesozoic Geology in France and related areas. Springer, 291-297.

Feist, R., \& Flajs, G. (1987a). Devonian and Carboniferous of the south-eastern Montagne Noire - Guidebook. International Union of Geological Sciences, Commission on Stratigraphy, working group on the Devonian/Carboniferous boundary, Montpellier, 91 p.

Feist, R., \& Flajs, G. (1987b). La limite Dévonien-Carbonifère dans la Montagne Noire (France). Biostratigraphy et environnement. Comptes rendus de l'Académie des Sciences Paris, 305/ II, 1537-1544.

Feist, R., Flajs, G., \& Girard, C. (2000). The stratotype section of the Devonian-Carboniferous Boundary. Courier Forschungsinstitut Senckenberg, 225, 77-82.

Feist, R., Lemke, U., \& Korn, D. (2000). Trilobiten aus der Wocklumeria-Stufe des höchsten Oberdevon von Apricke, Sauerland. Senckenbergiana lethaea, 79 (2), 517-539.

Feist, R., \& Petersen, M.S. (1995). Origin and spread of Pudoproetus, a survivor of the Late Devonian trilobite crisis. Journal of Paleontology, 69, 99-109.

Flajs, G., \& Feist, R. (1988). Index conodonts, trilobites and environment of the DevonianCarboniferous boundary Beds at La Serre (Montagne Noire, France. In G. Flajs, R. Feist and W. Ziegler (Eds.), Devonian-Carboniferous boundary - Results of recent studies. Courier Forschungsinstitut Senckenberg, 100, 53-107.

Galtier, J., Feist, R., Meyer-Berthaud, B., Rex, G., \& Rowe, N. (1987). Découverte d'une flore en compression dans les niveaux à lydiennes du Tournaisien de la Montagne Noire (Hérault, France). Comptes rendus de l'Académie des Sciences, Série II, 305, 647-651.

Gauchey, S., Girard, C., Adnet, S., \& Renaud, S. 2014. Unsuspected functional disparity in Devonian fishes revealed by tooth morphometrics? Naturwissenschaften, 101, 735-743

Girard, C. (1994). Conodont biofacies and Event stratigraphy across the D-C boundary in the stratotype area (Montagne Noire, France). In P. Königshof and R. Werner, R. (Eds), Willi Ziegler Festschrift I. Courier Forschungsinstitut Senckenberg, 168, 299-309.

Girard, C., Cornée, J.-J., Corradini, C., Fravalo, A., \& Feist, R. (2014). Palaeoenvironmental changes at Col des Tribes (Montagne Noire, France), a reference section for the Famennian of north Gondwana-related areas. Geological Magazine, 151, 864-884.

Huddle, J.H. (1934). Conodonts from the New Albany Shale of Indiana. Bulletin of American Paleontology, 72, $113 \mathrm{p}$. 
Ji, Q. (1985). Study on the phylogeny, taxonomy, zonation and biofacies of Siphonodella (Conodonta). Bulletin of the Institute of Geology Chinese Academy of Geological Sciences, $11,70-79$.

Ji, Q., Wang, Z., Sheng, H., Hou, J., Feng, R., Wei, J. Wang, S., Wang ,H., Xiang, L.\& Fu, G. (1989). The Dapoushang section. An excellent section for the Devonian-Carboniferous boundary stratotype in China. Sciences Press Beijing, 1-165.

Kaiser, S.I. (2009). The Devonian/Carboniferous boundary stratotype section (La Serre, France) revisited. Newsletters on Stratigraphy, 43/2, 195-205.

Kaiser, S.I., Becker, R.T., Spalletta, C., \& Steuber, T. (2009). High-resolution conodont stratigraphy, biofacies, and sea-level changes around the Hangenberg Event in pelagic successions from Austria, Italy, and France. Palaeontographica Americana, 63, 97-139.

Kaiser, S.I., Steuber, T., \& Becker, R.T. (2008). Environmental change during the late Famennian and early Tournaisian (Late Devonian-Early Carboniferous) - implications from stable isotopes and conodont biofacies in southern Europe. In M. Aretz, H.-G. Herbig and I. D. Somerville (Eds.), Carboniferous Platforms and Basins. Geological Journal, 43, 241-260.

Korn, D. (2005). Carboniferous ammonoid stratigraphy based on poorly preserved material a discussion of Becker \& Weyer (2004). Mitteilungen aus dem GeologischPaläontologischen Institut der Universität Hamburg, 89, 49-54.

Korn, D., \& Feist, R. (2007). Early Carboniferous ammonoid faunas and stratigraphy of the Montagne Noire (France). Fossil Record, 10, 99-124.

Legrand-Blain, M., \& Martinez Chacon, M.-L. (1988). Brachiopods at the DevonianCarboniferous boundary, La Serre (Montagne Noire; Hérault, France): preliminary report. In G. Flajs, R. Feist and W. Ziegler (Eds), Devonian-Carboniferous boundary - Results of recent studies. Courier Forschungsinstitut Senckenberg, 100, 119-127.

Lerosey-Aubril, R., \& Feist, R. (2005). First Carboniferous Protaspis larvae (Trilobita). Journal of Paleontology, 79(4), 702-718.

Lethiers, F., \& Feist, R. (1991). Ostracodes, stratigraphie et bathymétrie du passage DévonienCarbonifère au Viséen inférieur en Montagne Noire (France). Geobios, 24, 71-104.

Merzeraud, G. (2017). Sédimentologie. DeBoeck-Supérieur, Paris, 272 p.

Michel, D. (1981). Paléoenvironnement des calcaires noduleux et lydiennes en Montagne Noire (Dévonien supérieur-Dinantien). Thèse $3^{e}$ cycle, Orsay, 385 p. (unpublished). 
Michels, D. (1986). Ökologie und Fazies des jüngsten Ober-Devon von Velbert (Rheinisches Schiefergebirge). Göttinger Arbeiten zur Geologie und Paläontologie, 29, 1-86.

Paproth, E., Feist, R., \& Flajs, G. (1991). Decision on the Devonian-Carboniferous boundary stratotype. Episodes, 14(4), 331-336.

Phillips, J. (1841). Figures and Descriptions of the Palaeozoic Fossils of Cornwall, Devon, and West Somerset. Longman, London, 231 p.

Richter, R. (1913). Beiträge zur Kenntnis devonischer Trilobiten, II. Oberdevonische Proetiden. Abhandlungen der senckenbergischen naturforschenden Gesellschaft, 31, 345423.

Richter, R. \& Richter, E. (1926). Beiträge zur Kenntnis devonischer Trilobiten, IV. Die Trilobiten des Oberdevons. Abhandlungen der Preussischen Geologischen Landesanstalt, n.F. 99, 1-314.

Richter, R. \& Richter, E. (1951). Der Beginn des Karbons im Wechsel der Trilobiten. Senckenbergiana, 32 (1/4), 219-266.

Semenoff-Tian-Chansky, P. (1988). Corals from the Devonian-Carboniferous boundary at La Serre (Montagne Noire, France). - In G. Flajs, R. Feist \& W. Ziegler (Eds.), DevonianCarboniferous boundary - Results of recent studies. Courier Forschungsinstitut Senckenberg, 100, 129-138.

Vachard, D. (1988). Calcareous microfossils (Algae, Pseudo-Algae and Foraminifera) from La Serre, Montagne Noire, France. In G. Flajs, R. Feist and W. Ziegler (Eds.), DevonianCarboniferous boundary - Results of recent studies. Courier Forschungsinstitut Senckenberg, 100, 137-147.

Vachard D., Izart, A., \& Cózar, P. (2017). Mississippian (middle Tournaisian-late Serpukhovian) lithostratigraphic and tectonosedimentary units of the southeastern Montagne Noire (Hérault, France). Géologie de la France, 1, 47-88.

Wiederer, U., Königshof, P., Feist, R., Franke, W., \& Doublier, M. (2002): Low grade metamorphism in the Montagne Noire (S-France): Conodont Alteration Index (CAI) in Palaeozoic carbonates and implications for the exhumation of a hot metamorphic core complex. Schweizer Mineralogische und Petrographische Mitteilungen, 82, 393-407.

Wright, V.P., \& Burchette, T.P. (1996). Shallow-water carbonate environments. In H.G. Reading (Ed.), Sedimentary Environments: Processes, Facies, and Stratigraphy (pp. 325394). Oxford: Blackwell Science. 
Yuan, J., \& Xiang, L. (1998). Trilobite fauna at the Devonian-Carboniferous boundary in South China (S-Guizhou and N-Guangxi). Special Publication 8, National Museum of Natural Science, Taiwan, 1-281.

Ziegler W. (1959). Conodonten aus Devon und Karbon Südwesteuropas und Bemerkungen zur bretonischen Faltung (Montagne Noire, Massiv v. Mouthoumet, Span. Pyrenäen). Neues Jahrbuch für Geologie und Paläontologie. Monatshefte, 7, 289-309.

Ziegler, W. (1969). Eine neue Conodontenfauna aus dem höchsten Oberdevon. Fortschritte Geologie von Rheinland und Westfalen, 17, 179-191.

Ziegler, W. \& Leuteritz, K. (1970). Alter, Fazies und Paläogeographie der Oberdevon / Unterkarbon-Schichtenfolge an der Seiler bei Iserlohn. Fortschritte Geologie von Rheinland und Westfalen, 17, 679-732

Ziegler W., \& Sandberg, C.A. (1996) Reflexions on Frasnian and Famennian Stage boundary decisions as a guide to future deliberations. Newsletters on Stratigraphy, 33, 157-180.

\section{Figure captions}

Fig.1. Geological map of Devonian and early Carboniferous deposits in the south-eastern Montagne Noire (Mont Peyroux nappe and klippen of Cabrières) after Engel et al. (1980-81). a: location of the Montagne Noire (France); b: situation of Devonian-lower Tournaisian in the nappes and Cabrières klippen of the southern Montagne Noire; c: location of D-C boundary sections: La Serre (GSSP), Puech de la Suque, Col des Tribes, Pic de Bissous. Lithostratigraphic terms after Korn and Feist (2007). Modified from Aretz (2016).

Fig. 2. Field views: a. Trenched stratotype section E' at La Serre. The GSSP of the D-C boundary was ratified at the base of Bed 89 within the upper oolitic unit. b. Inverted DCB section at Col des Tribes. The excavation corresponds to the Hangenberg Shale interval. c. Inverted Hangenberg Black Shale (HBS) equivalent topped by yellow mudstone (star) at Puech de la Suque; Bed PS 9 = Bed 90 in Girard (1994), and on Figure 6 (this study); first Protognathodus kockeli in superseding limestone nodules (Bed PS 10a). Scale: the hammer is $40 \mathrm{~cm}$ long. 
Fig. 3. a-d: carbonate microfacies of the pre-HBS latest Famennian limestone and the post-

HBS lower and upper oolitic units in the stratotype section La Serre E' (described in Flajs and Feist (1988) and Casier et al. (2002)); a: calcisiltite; b-c: coarse-grained lithic oolitic grainstone; d: oolitic wackestone to packstone with brachiopods-oolites are tangential to radial. Right: $\log$ of the section and ranges of important conodont species. Legend: Oo: oolite, Br: brachiopod, Ex: extraclast, Ech: echinoid. Abbreviations: ac.: aculeatus; c.: communis; g.: gracilis; p.: purus. Green line: the D-C Boundary, dotted lines: base of conodont zones. Conodont Zones after Corradini et al. (2017).

Fig. 4 Significant oculated trilobites in topmost Wocklumeria Limestones of the stratotype section LS-E', Bed 68 at La Serre. Deposit: Collections of Montpellier University (UM-IP). a-c Omegops accipitrinus (Phillips, 1841), (a) fragmentary cephalon UM-IP 839, dorsal view, (b) fragmentary cephalon UM-IP 840, lateral view, (c) pygidium UM-IP 841, dorsal view. d-e Rabienops wedekindi (Richter and Richter, 1926), (d) cephalon, dorsal view, (e) pygidium, dorsal view. f-h Pseudowaribole sp. A aff. macrops Yuan, 1988 in Yuan and Xiang, 1998, (f) incomplete cranidium UM-IP 842, dorsal view, (g) juvenile cranidium UM-IP 843, dorsal view, (h) incomplete librigena UM-IP 844, dorsal view. i-j Pseudowaribole conifera Richter and Richter, 1926, (i) incomplete cranidium UM-IP 845, dorsal view, (j) pygidium UM-IP 846, dorsal view. k Waribole warsteinensis Richter and Richter, 1926, pygidium UM-IP 847, dorsal view. Scale bars correspond to $0.5 \mathrm{~mm}$.

Fig. 5. Facies and depositional environment in section La Serre F and C. a-d (LS-F): a: lithostratigraphic succession. b: cm-bedded limestone of the lower calcoolitic unit. c: erosional surface, plane view; arrow indicates dissolution of Bed 21. d: erosional surface, perpendicular view; arrow indicates dissolution of Bed 21. e: (LS-C): lithostratigraphic succession; numbering of beds is from Cifer et al. (2017).

Fig. 6. Stratigraphically significant conodonts from the base of the Carboniferous. The material is stored in the collections of Montpellier University (UM CND). a: Protognathodus kockeli (Bischoff, 1957), upper view of element UM CND 1 (Col des Tribes, level DC2); b: Protognathodus kockeli (Bischoff, 1957) transitional form to Pr. kuehni Ziegler and Leuteritz, 1970, upper view of element UM CND 2 (Puech de la Suque, PS10A); c: Siphonodella bransoni Ji, 1985, upper view of element UM CND 3 (Puech de la Suque, PS13); d-e: ?Siphonodella cf. bransoni (LSE' 98), d: upper view of element UM CND 4, e: lower view of 
element UM CND 4; f: Protognathodus kuehni Ziegler and Leuteritz, 1970, upper view of element UM CND 5 (Col des Tribes, DC4); g: Protognathodus collinsoni Ziegler, 1969, upper view of element UM CND 6 (La Serre trench F, LSF21); h: Protognathodus collinsoni Ziegler, 1969, transitional form to Pr. kockeli Bischoff, 1957 upper view of element UM CND 7 (La Serre trench F, LSF21), i-j: Siphonodella bransoni Ji, 1985 i: upper view of element UM CND 8, j: lower view of element UM CND 8 (La Serre E', LSE' 98)

Fig. 7. Devonian-Carboniferous transition at Col des Tribes section. Left: carbonate microfacies: wackestones with cephalopods, crinoids and benthic ostracods. Right: log of the section and distribution of conodont species. Green line: the D-C Boundary, dotted lines: base of conodont zones. Conodont zones after Becker et al. (2016b) and Corradini et al. (2017). Legend: Ech: echinoid, G: ammonoid; T: trilobite; Ob: benthic ostracod. Abbreviations: $B i$.: Bispathodus, Br.: Branmehla, Pa.: Palmatolepis, Po.: Polygnathus, Pr.: Protognathodus, Ps.: Pseudopolygnathus, Si.: Siphonodella, com.: communis, gr.: gracilis, HBS: Hangenberg Shale.

Fig. 8. Stratigraphically and palaeoecologically significant blind and reduced-eyed trilobites in topmost Wocklumeria Limestones at Col des Tribes (e) and Puech de la Suque (b-d), oculated trilobites from the Pr. kockeli Zone at Puech de la Suque (f-k), blind trilobite from the Si.quadruplicata Zone at Puech de la Suque (a) and Col des Tribes. Deposit: Collections of Montpellier University (UM-IP). a Liobolina sp., cephalo-thorax with displaced librigena UM-IP 848, b-c Struveproetus ocellatus Feist in Feist et al., 2000, (b) cephalon UM-IP 849, lateral view, (c) dorsal view, d Chaunoproetus palensis (Richter, 1913), pygidium UM-IP 850, dorsal view, (e) Haasproetus cf. aprickensis (Feist in Feist et al., 2000), incomplete pygidium UM-IP 851, dorsal view, f-h Winterbergia (?Eowinterbergia) funirepa Feist in Flajs and Feist, 1988, (f) librigena UM-IP 852, dorsal view, (g) cranidium UM-IP 853, dorsal view, (h) pygidium UM-IP 854, dorsal view, i-k Belgibole abruptirhachis (Richter and Richter, 1951), (i) fragmentary cranidium UM-IP 855, dorsal view, (j) librigena UM-IP 856, dorsal view, (k) juvenile pygidium UM-IP 857, dorsal view. Scale bars correspond to $0.5 \mathrm{~mm}$.

Fig. 9. Devonian-Carboniferous transition at Puech de la Suque section. Left: carbonate microfacies. Right: $\log$ of the section and distribution of conodont species. Green line: the DC Boundary, dotted lines: base of conodont zones. Conodont zones after Becker et al. (2016b) and Corradini et al. (2017). Legend: F: filament, G: ammonoid, B: brachiopod; Ob: benthic 
ostracod; T: trilobite. Abbreviations: Bi.: Bispathodus, Br.: Branmehla, M.: Mehlina, Pa.:

Palmatolepis, Po.: Polygnathus, Pr.: Protognathodus, Ps.: Pseudopolygnathus, Si.: Siphonodella, ac.: aculeatus, c.: communis, gr.: gracilis, m.: marburgensis, p.: purus, tr.: triangulus. HBS: Hangenberg Shale.

Fig. 10. X-ray analysis of the Hangenberg Black Shale (HBS) equivalent at Puech de la Suque section. The undulated surface at top of bed PS90 is locally coated by iron hydroxydes. This surface probably results in post depositional fluid circulations and dissolutions because of contrasting lithologies (limestones / shales) in the inverted and compacted succession. T/R: transgression/regression. HBS: Hangenberg Black Shale equivalent.

Fig. 11. Facies- and conodont-based correlations of D-C boundary sections from near-shore (klippen of Cabrières) to distal off-shore (nappes) environments. The red line indicates the end of the maximum regression. (a), a virtual coastal to basinal transect with HBS level in black (b) (after Flajs and Feist 1988, updated). Abbreviations: Bi.: Bispathodus, Pr.: Protognathodus, Ps.: Pseudopolygnathus, Si.: Siphonodella, tr.: triangulus. 


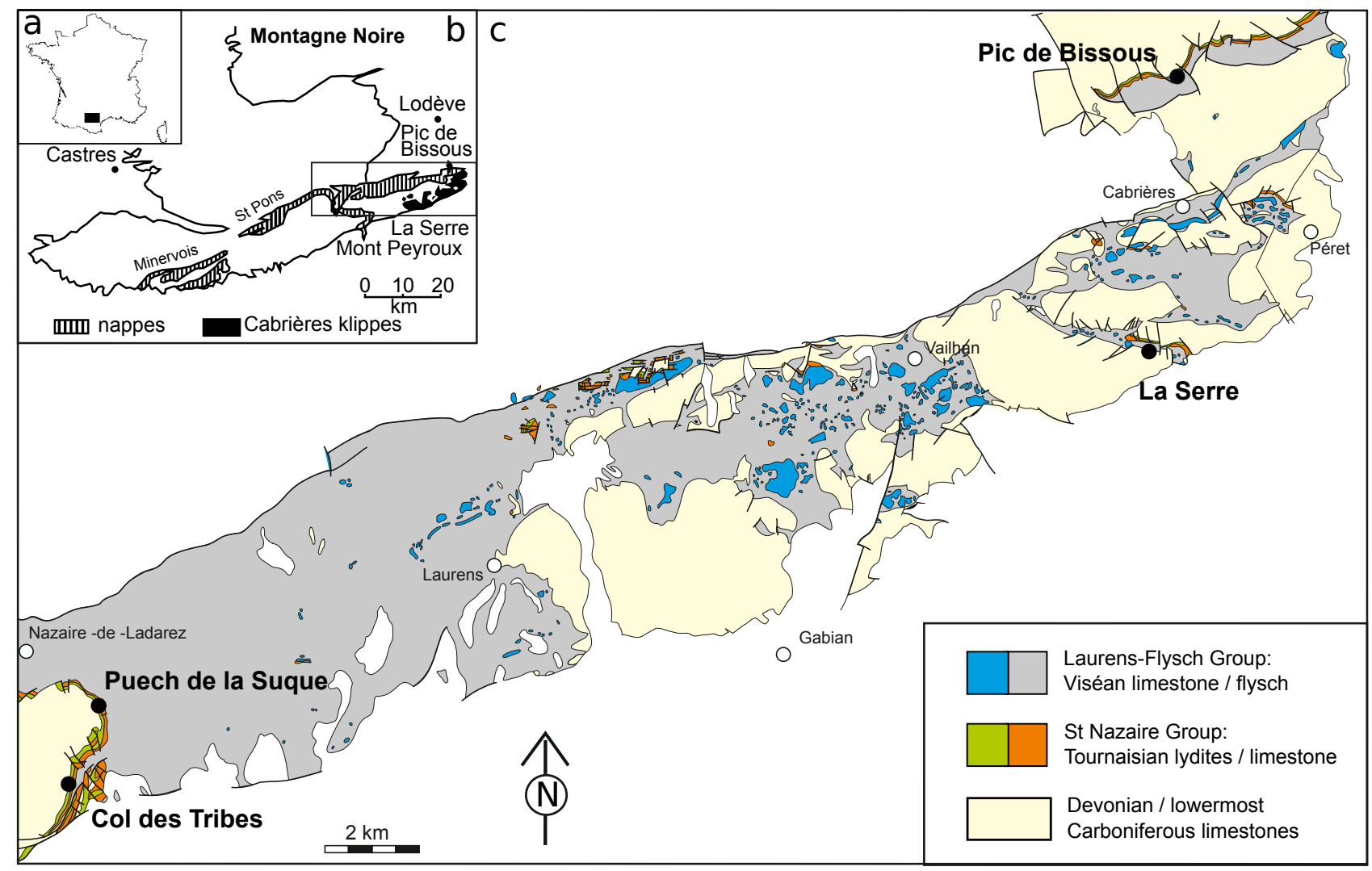



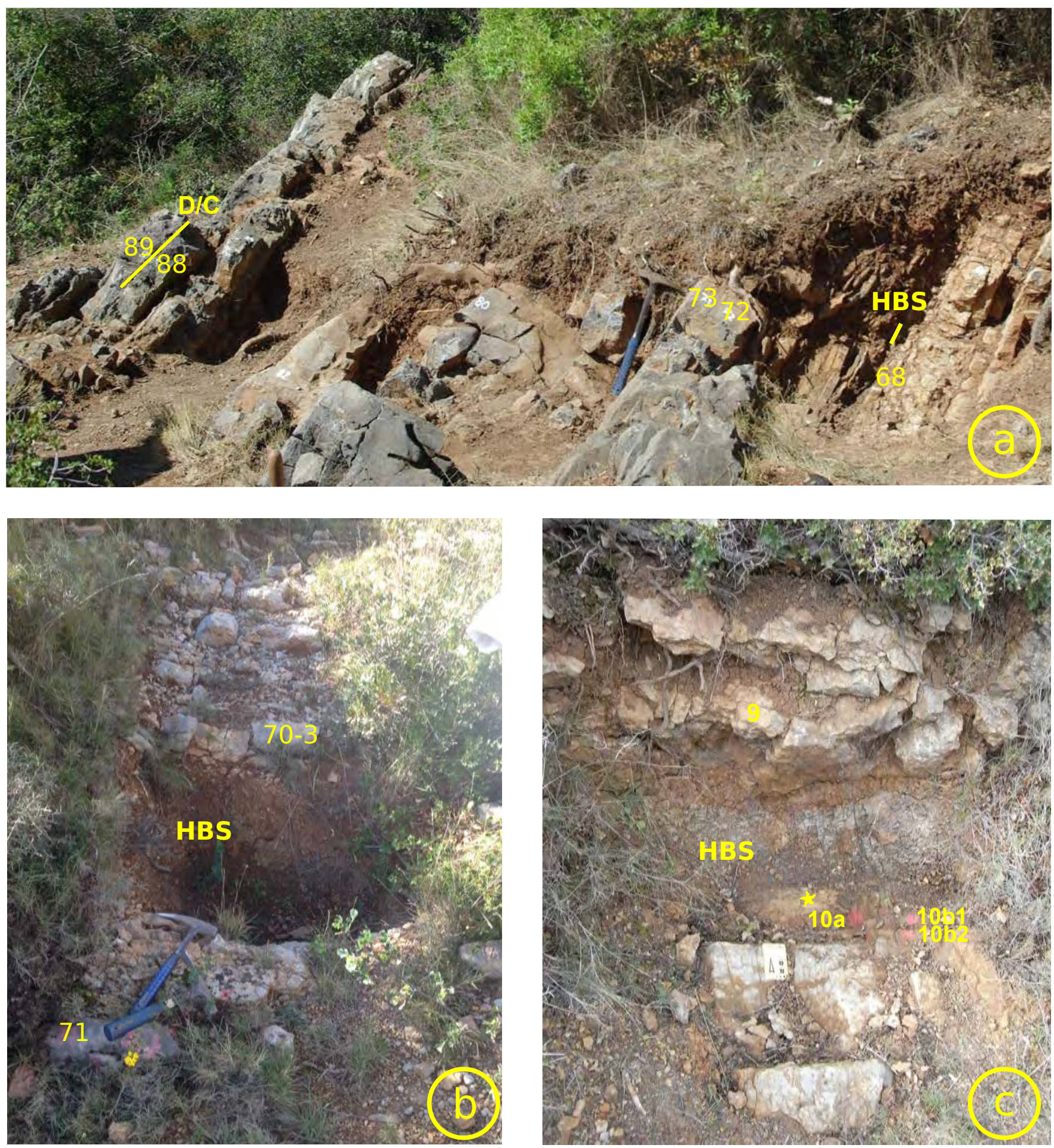

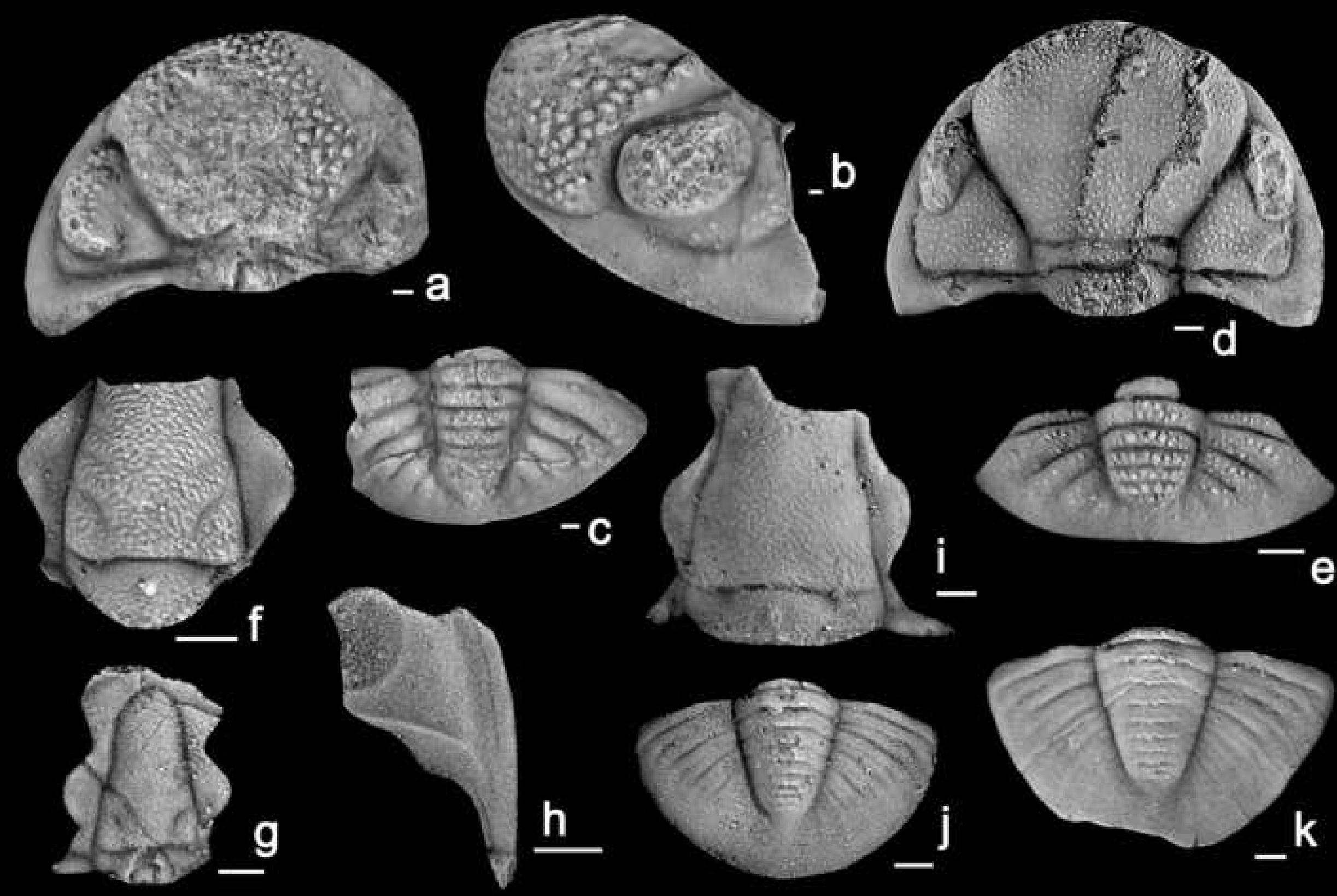
Figure 6

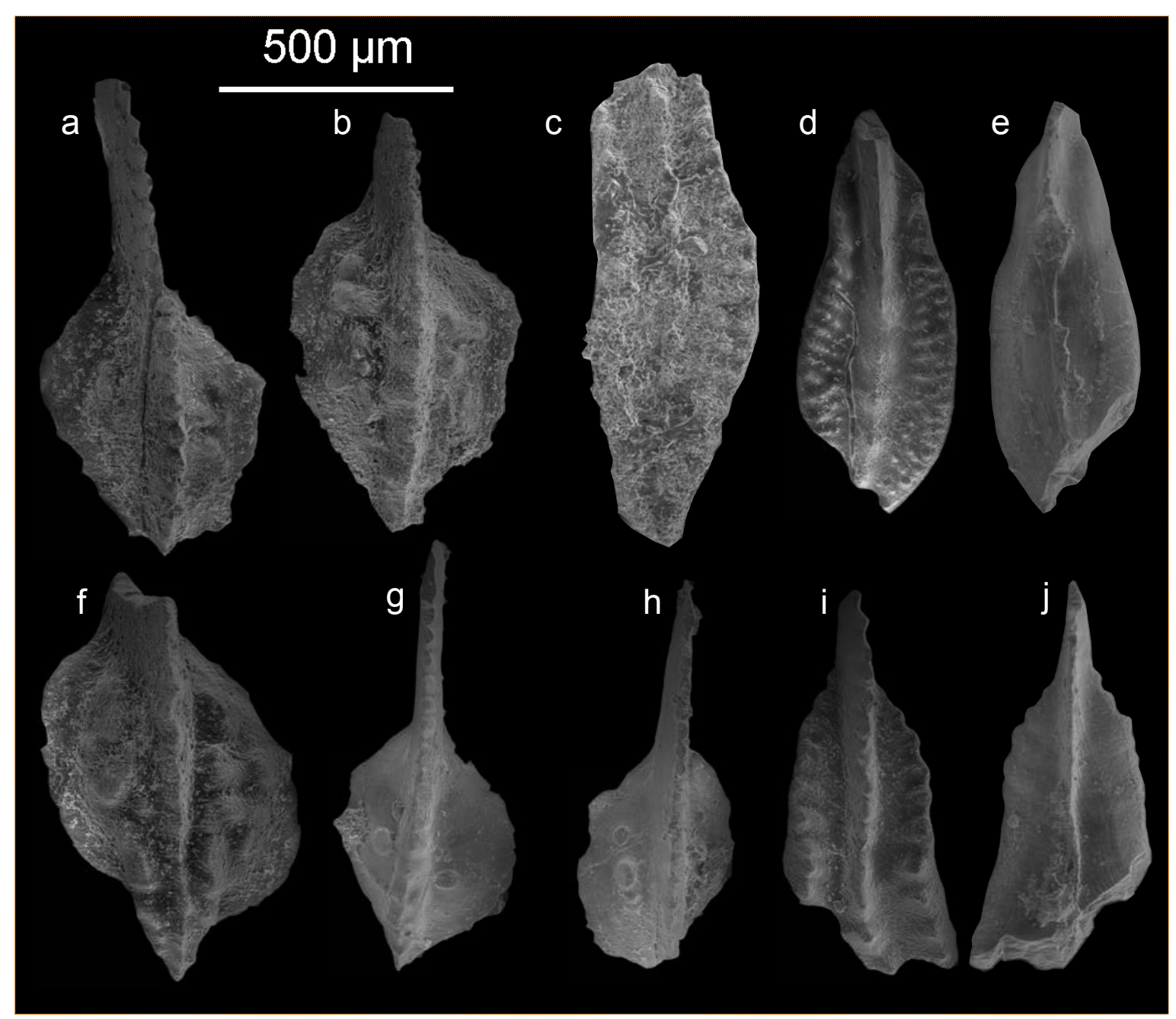

h 


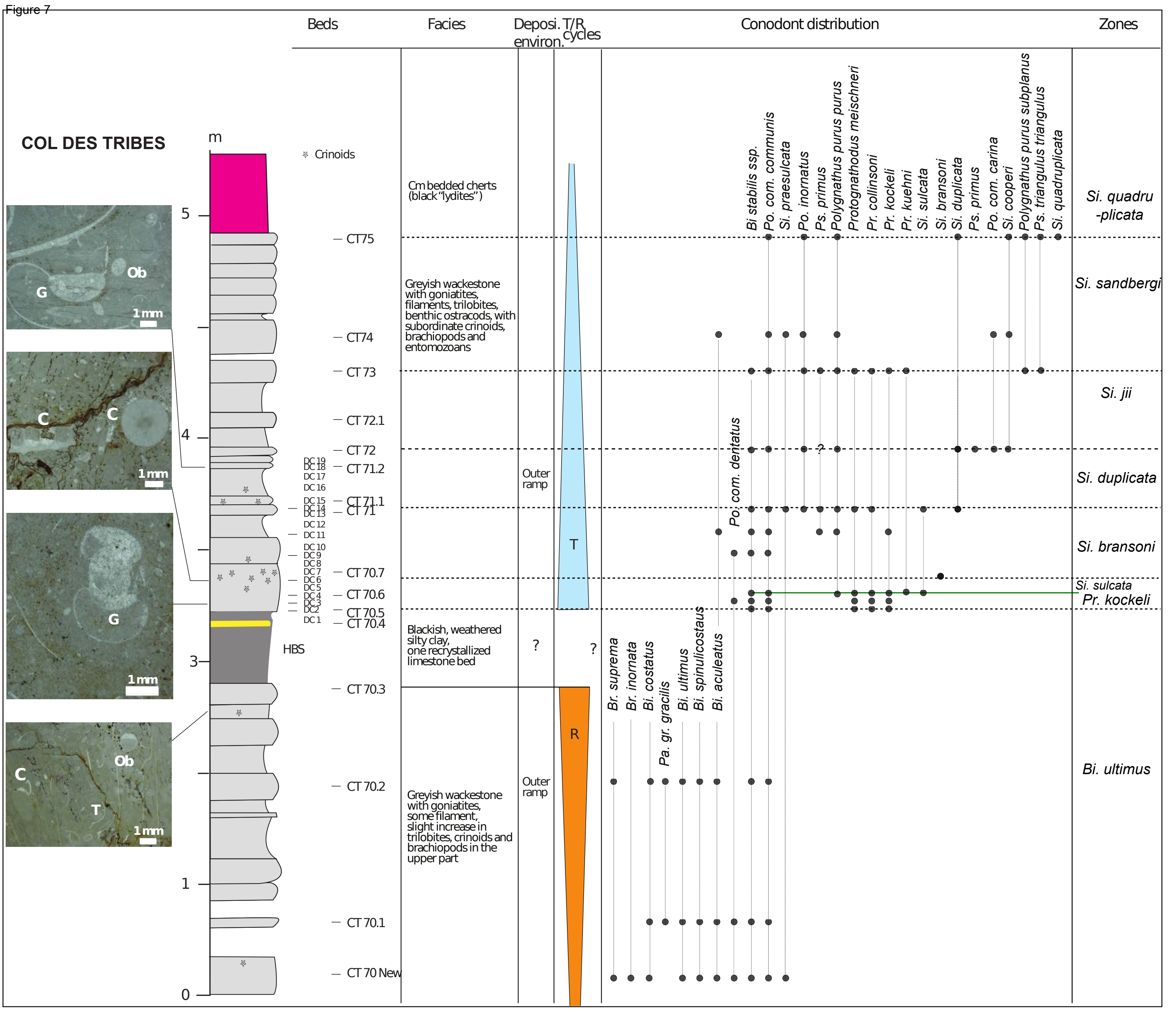




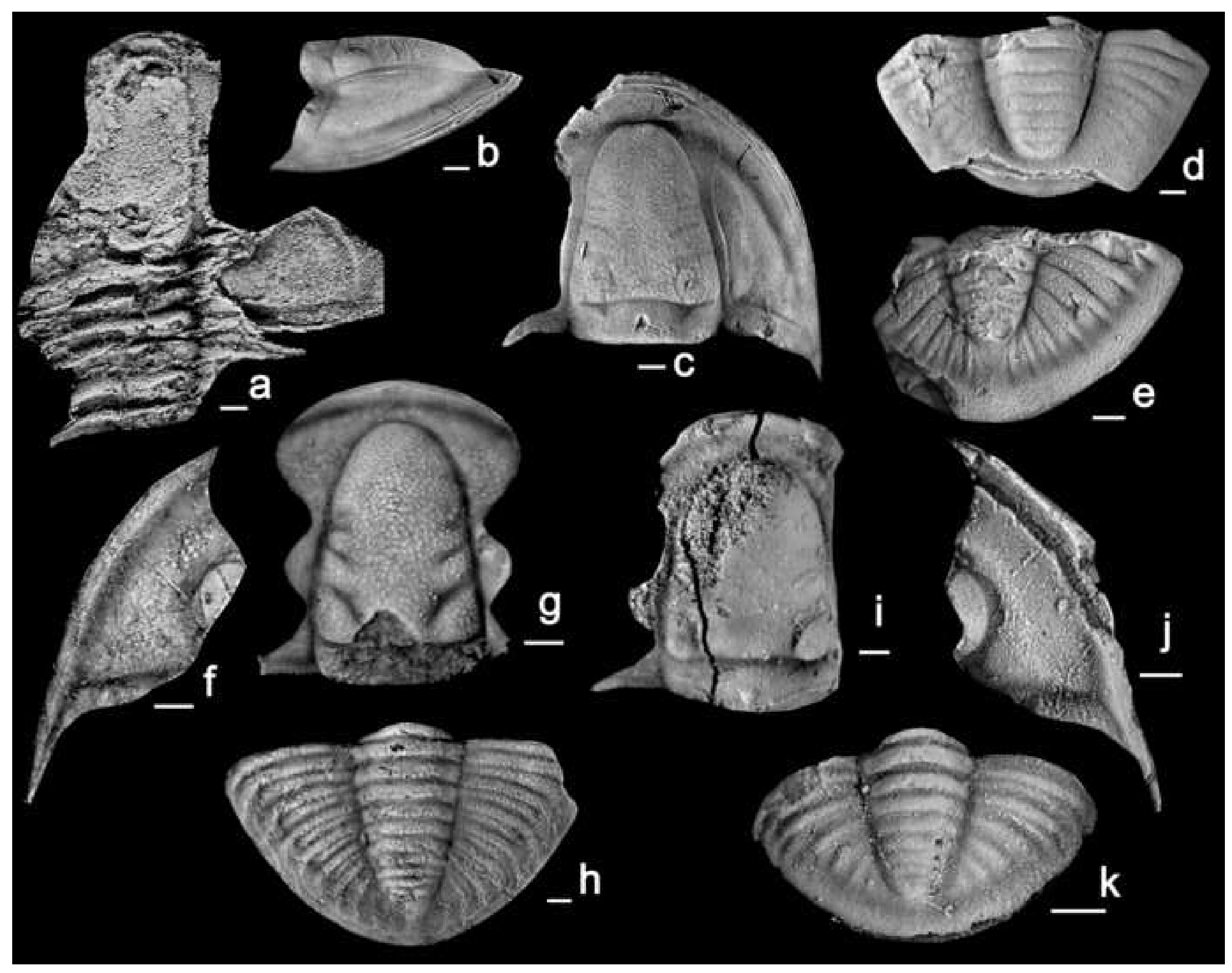


Thin sections, natural light
Samples
Semi quantitative Relative T/Rcycles estimate from RXanalysis sea level
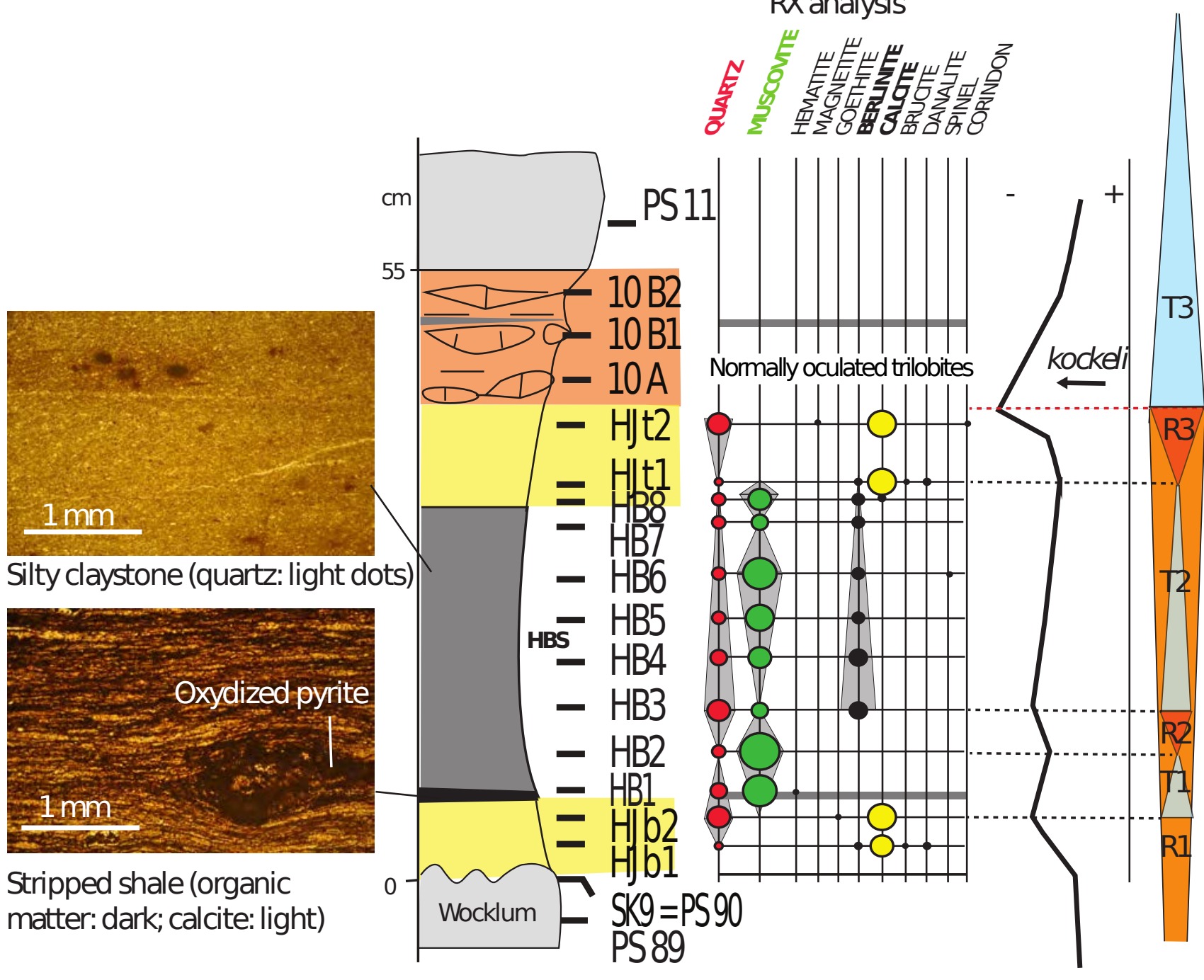

matter: dark; calcite: light)

Percentages

70/80 \% 60/70\% 50/60\% 40/50\% 30/40\% 20/30\% 10/20\% Present/10\% Trends: Decrease $\triangle$ Increase $\nabla$ 


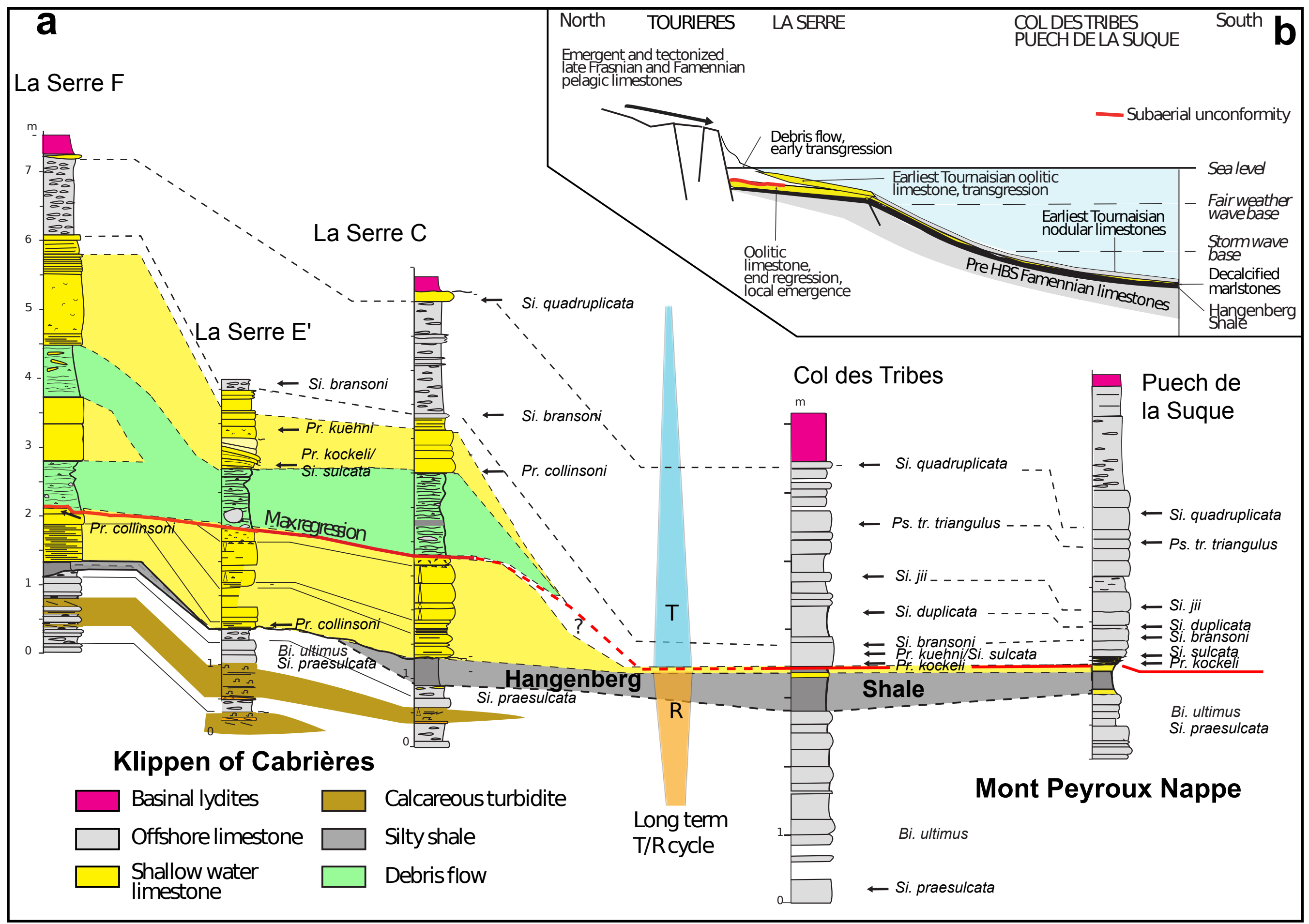

